\title{
PENGARUH PEMANFAATAN SIMARI SEBAGAI IMPLEMENTASI PEMBELAJARAN BERBASIS E-LEARNING TERHADAP HASIL BELAJAR MAHASISWA PRODI PENDIDIKAN EKONOMI
}

\author{
Meliyani, Supriyanto, Muhammad Rahmattullah \\ Pendidikan Ekonomi, Universitas Lambung Mangkurat \\ e-mail: mrahmattullah@ulm.ac.id
}

\begin{abstract}
Utilization of SIMARI (Integrated Lambung Mangkurat University Information System) as a form of implementation of the application of e-learning in learning, has begun at Lambung Mangkurat University, especially in the Economic Education Study Program since the even semester of the academic year 2017/2018. The problem that arises is that there are still limited subjects applying SIMARI. This study aims to analyze the effect of SIMARI utilization as the implementation of elearning based learning on the learning outcomes of ULM FKIP Economics Education students. Research uses a quantitative approach. The population in this study were all students of the Economic Education Study Program who had participated in e-learning totaling 291 people. Samples were taken as much as $25 \%$, namely 73 people with stratified sample techniques. Data were collected through questionnaires related to SIMARI utilization in learning as independent variables and documentation of student learning outcomes in subjects that had used SIMARI as the dependent variable. Data were analyzed using simple regression techniques. The results showed that SIMARI utilization in e-learning was in a fairly good category. Student learning outcomes are in a fairly high category. There is a significant effect of SIMARI utilization as the implementation of e-learning based learning on student learning outcomes which is indicated by the Fcount of 4.554 with a significance of 0.036. It was concluded that SIMARI's utilization as an implementation of e-learning in learning could significantly improve student learning outcomes especially in the ULM FKIP Economic Education Study Program.
\end{abstract}

Keywords: SIMARI, e-learning, learning outcomes. 


\section{PENDAHULUAN}

Pendidikan dalam perguruan tinggi diharapkan mampu memberikan pembelajaran yang bermakna, berguna dan meningkatkan kemampuan mahasiswa untuk terjun dalam dunia nyata. Karena itu semua daya upaya pembelajaran perlu difokuskan untuk mencapai pembelajaran yang optimal. Pembelajaran yang optimal perlu sarana, strategi dan teknologi yang terbaik untuk dapat menunjang hal tersebut. Salah satu yang perlu dipertimbangkan adalah penggunaan teknologi informasi dalam menunjang pembelajaran di perguruan tinggi.

Kegiatan pembelajaran harus memiliki satu komponen yang perlu diperhatikan agar suatu pembelajaran dapat berkesinambungan dan memberikan pengaruh dalam pelaksanaannya. Komponen tersebut yaitu desain, aplikasi/implementasi, dan manajemen atau maintenance. Berkaitan dengan pembelajaran, pemanfaatan teknologi informasi sangat diperlukan dalam menunjang kegiatan belajar mengajar.

Perkembangan teknologi internet dalam proses belajar mengajar yang sudah dimanfaatkan salah satunya E-learning. Dengan adanya E-learning diharapkan mampu mengatasi kendala perluasan dan pemerataan kesempatan memperoleh pendidikan dengan pemanfaatan teknologi jaringan dan aplikasi internet. Berbagai informasi yang ditampilkan dalam E-learning untuk pendidikan ini merupakan suatu terobosan yang sangat strategis dalam menerapkan teknologi baru pada kegiatan sistem informasi pada lingkup dunia pendidikan. Dengan adanya Elearning untuk pendidikan ini maka kebutuhan akan informasi selalu tersedia dan dapat diakses oleh mahasiswa dengan mudah dan cepat. E-learning untuk pendidikan ini akan menjadikan pelayanan terhadap mahasiswa menjadi lebih baik.

Departemen Pendidikan Nasional sebagai organisasi yang berfungsi mengelola pendidikan di Indonesia menyambut baik perkembangan ICT dengan memasukkan kurikulum yang bernuansa pengenalan teknologi informasi dan komunikasi. Selain itu, Departemen Pendidikan Nasional juga menganggap bahwa dalam suatu organisasi, kinerjanya didukung oleh dua hal yaitu kinerja kelompok maupun kinerja individunya. Perguruan Tinggi yang kinerjanya didukung oleh kinerja Jurusan, Mahasiswa, dan seterusnya. Setiap pekerja atau pegawai yang bekerja di sebuah instansi bisa dikatakan kinerjanya bagus jika dapat fokus pada pekerjaannya. Kinerja atau prestasi belajar mahasiswa dikatakan bagus jika mahasiswa menjalankan tugas kuliah dengan baik. Namun sangat disayangkan, masih banyak mahasiswa yang tidak mengerti bahwa kinerja mereka sangat berpengaruh pada kinerja perguruan tinggi tempat mereka menuntut ilmu. Ada suatu Indikator kinerja bagi mahasiswa yang meliputi indeks prestasi kumulatif (IPK), lama studi, efisiensi lulusan dan waktu tunggu lulusan.

Menurut Darmawan (2014) E-learning merupakan kombinasi antara informasi, interaksi dan komunikasi pendidikan yang merupakan elemen-elemen inti dalam strategi mencapai keberhasilan. Dalam hal ini e-learning menyangkut solusi terhadap tantangan pembaruan (updates). Di dalam e-learning peserta didik mempunyai pilihan untuk menetapkan isi (collaborative solution) dan kecepatan (self-pace). Pendidik dapat memberikan materi pelajarannya lewat sarana internet yang dapat diakses setiap saat di mana saja. Peserta didik juga tidak perlu harus selalu belajar di kelas untuk mendapatkan informasi mengenai materi yang 
diperolehnya. Bahkan peserta didik dapat mengembangkan proses belajarnya dengan mencari referensi dan informasi dari sumber lain.

Seorang pendidik harus mampu merancang teknik pembelajaran yang inovatif, kreatif dengan menggunakan pembelajaran berbasis teknologi (Kristiawan, 2014). Berbagai macam sumber belajar berbasis teknologi atau digital dapat diterapkan dalam proses pembelajaran (Yustanti dan Novita, 2019). E-learning merupakan inovasi yang dapat dimanfaatkan dalam proses pembelajaran, tidak hanya dalam penyampaian materi pembelajaran tetapi juga perubahan dalam kemampuan berbagai kompetensi peserta didik (Elyas, 2018).

Universitas Lambung Mangkurat telah mengimplementasikan E-learning pada semester genap tahun ajaran 2017/2018 sampai sekarang yang dikembangkan dan telah digunakan sebagai salah satu bentuk pembelajaran yang diakui oleh pimpinan universitas. Saat ini, penerapan e-learning di Universitas Lambung Mangkurat dilaksanakan secara terintegrasi melalui Sistem Informasi Universitas Lambung Mangkurat Terintegrasi (SIMARI). Pembelajaran dengan pemanfaatan SIMARI merupakan salah satu upaya untuk mendukung berbagai aktivitas dosen, mahasiswa, dan semua pihak yang berkepentingan khususnya terkait aktivitas pembelajaran yang mencakup penyampaian materi pembelajaran dan penilaian tugas yang bermuara ke arah efektifitas dan peningkatan kualitas proses serta hasil belajar. Dari Data Keefektifan e-learning ULM, di tingkat universitas sudah ada 384 dosen, 1192 mata kuliah dan 12409 mahasiswa yang telah menggunkan Elearning sebagai media pembelajaran. Di lingkungan Fakultas Keguruan dan Ilmu pada tahun 2018 dari 253 dosen hanya 110 atau 43,48\% dosen dan dari 8277 mahasiswa hanya 3713 atau 44,86\% mahasiswa menggunakan e-learning dalam proses pembelajaran. Hal ini dirasa belum optimal Karena masih banyaknya dosen yang belum menerapkan E-learning dalam perkuliahan.

Permanfatan teknologi informasi di lingkungan FKIP ULM rupanya sudah digunakan oleh mahasiswa dan dosen. Bukti dari pemanfaatan teknologi informasi tersebut adalah adanya pembelajaran melalui media e-learning. E-learning merupakan salah satu media teknologi informasi bagi mahasiswa dan dosen dalam proses belajar. Hal tersebut menimbulkan reaksi psikologi terhadap teknologi informasi tersebut sehingga berpengaruh pada tingkat penerimaan materi kuliah dari pada prestasi belajar mahasiswa. Dengan adanya media tersebut mahasiswa dapat memperdalam pengetahuan tentang pelajaran yang diajarkan oleh dosen, sehingga berpengaruh terhadap prestasi belajar mahasiswa. Secara tidak langsung mahasiswa dituntut untuk turut aktif dalam meningkatkan kinerja individu terhadap pemanfaatan teknologi informasi yang dari tahun ke tahun semakin meningkat. Dengan adanya perbedaan karakteristik pemakaian secara individual dapat menyebabkan perbedaan dalam pencapaian tujuan sehingga kinerja individu akan terpengaruh.

Observasi awal yang dilakukan di lingkungan Fakultas Keguruan dan Ilmu Pendidikan khususnya di Prodi Pendidikan Ekonomi menunjukan bahwa jumlah dosen yang menggunakan SIMARI dalam pembelajaran hanya terbatas pada beberapa mata kuliah. Dari wawancara dengan sejumlah mahasiswa diperoleh informasi awal pembelajaran e-learning bagus untuk diterapkan karena lebih mempermudahkan dalam proses pembelajaran, lebih praktis dan efesien waktu. Akan tetapi ada beberapa kesulitan yang dialami mahasiswa dengan pembelajaran 
e-learning yaitu kadang server error, koneksi internet yang kurang lancar dan pemahaman mahasiswa yang kurang dalam menggunakan e-learning. Belum dilakukan penelitian terkait pengaruh pemanfaatan SIMARI terhadap hasil belajar mahasiswa khususnya di prodi Pendidikan Ekonomi.

E-learning merupakan aplikasi internet yang dapat menghubungkan anatara pendidik dan peserta didik dalam sebuah belajar online. E-learning tercipta untuk mengatasi keterbatasan anta pendidik dan peserta didik, terutama dalam hal waktu, ruang, kondisi, dan keadaan. Melalui e-learning maka pendidik dan peserta didik tidak harus berada dalam satu demensi ruang dan waktu, proses pendidikan dapat berjalan kapan saja dengan mengabaikan dua hal tersebut.( Darmawan, 2014).

E-learning merupakan proses dan kegiatan penerapan pembelajaran bebasis web (web based learning), pembelajaran berbasis computer (computer based learning), kelas virtual (virtual class) dan/atau kelas digital (digital classroom). Materi-materi dalam kegiatan pembelajaran elektronik tersebut kebanyak dihantarkan melalui media internet, internet tape video atau audio, penyiaran melalui satelit, televisi interaktif serta CD-ROM. Definisi ini juga menyatakan bahwa definisi dari e-learning itu bisa bervariasi tergantung dari pennyelenggraan kegiatan e-learning tersebut dan bagaimana cara penggunaanya, termasuk juga apa tujuan penggunaanya (Rusman dkk.,2011) .

E-learning merupakan suatu penerapan teknologi informasi yang relatif baru di indonesia, mulai dikenal secara komersial pada 1995 katika IndoInternet membuka layanannya sebagai penyedia jasa layanan internet pertama. E-learning terdiri dua bagian, yaitu "e" yang merupakan singkatan dari 'electronic' dan learning' yang berarti 'pembelajaran'. Jadi e-learning berarti pembelajaran dengan menggunakan jasa/bantuan perangkat elektronika, khususnya perangkat komputer. Karena itu, s-Learning sering disebut pula on-line course (Soekarwati, 2003).

Penelitian yang dilakukan oleh Darliah (2016) menunjukan semakin tinggi penggunaan e-learning oleh mahasiswa maka motivasi belajar mahasiswa semakin meningkat dan semakin sering penggunaan e-learning oleh mahasiswa maka prestasi belajar mahasiswa juga akan meningkat. Penelitian lain oleh Ramadhani (2012) menunjukan bahwa peningkat hasil belajar dengan penggunaan media elearning lebih baik dibandingkan dengan peningkatan hasil belajar dengan penggunaan media pembelajaran konvensional. E-learning merupakan salah satu alternative media pembelajara interaktif yang mengembangkan sikap aktif, mandiri dan kreatif. Siswa dapat berperan secara aktif dalam memperoleh kesempatan membangun sendiri pengetahuan yang mendalam serta dalam proses pembelajaran yang lebih bervariatif.

Penelitian ini bertujuan untuk menganalisis pengaruh pemanfaatan SIMARI sebagai implementasi pembelajaran berbasis e-learning terhadap hasil belajar mahasiswa Pendidikan Ekonomi FKIP ULM. Melaluu penelitian ini diharapkan dapat memberikan manfaat dalam pengumpulan berbagai informasi terkait proses pemanfaatan SIMARI sebagai implementasi dari pembelajaran berbasis e-learning baik dari aspek proses pembelajaran maupun hambatan yang terjadi serta dampaknya terhadap hasil belajar mahasiswa. Informasi ini diharapkan dapat menjadi bagian dari basis data untuk upaya peningkatan kualitas SIMARI agar ke 
depannya bisa lebih efektif untuk digunakan dalam berbagai aktivitas khususnya terkait proses pembelajaran di berbagai level dalam lingkup Universitas Lambung Mangkurat.

\section{METODE PENELITIAN}

Penelitian ini merupakan penelitian ex post facto dengan pendekatan kuantitatif. Waktu penelitian dilaksanakan selama enam bulan yakni pada semester genap tahun ajaran 2018/2019. Tempat penelitian dilaksanakan di Program Studi Pendidikan Ekonomi FKIP Universitas Lambung Mangkurat. Populasi penelitian ini yakni seluruh mahasiswa Program Studi Pendidikan Ekonomi yang telah mengikuti pembelajaran berbasis e-learning dengan menggunakan SIMAI yang berjumlah sebanyak 291 orang. Sampel ditentukan sebanyak 25\% yakni sejumlah 73 orang dengan teknik sampel berstrata. Sampel berasal dari mahasiswa angkatan 2015, 2016, 2017, dan 2018.

Variabel dalam penelitian ini mencakup dua variabel yakni pemanfaatan SIMARI sebagai implementasi pembelajaran berbasis e-learning yang menjadi variabel bebas dan variabel hasil belajar mahasiswa sebagai variabel terikat. Variabel bebas yakni pemanfaatan SIMARI terdiri atas dua indikator mencakup: 1) penggunaan e-learning oleh mahasiswa yang terdiri atas: a) kesiapan dalam menggunakan elearning, b) Memanfaatkan materi, c) pemanfaatan kuis, d) pemanfaatan tugas, e) pemanfaatan forum diskusi, f) pemanfaatan chat, g) penghematan waktu, h) penghemaatn biaya, i) monitoring aktivitas mahasiswa, dan j) respon terhadap pembelajaran; serta 2) hambatan dalam penggunaan elearning yang terdiri atas: a) koneksi internet, b) keterbatasan interaksi, c) keterbatasan pemahaman, dan d) waktu. Variabel bebas diukur dengan menggunakan kuesioner dengan skala 4 yang diisi oleh mahasiswa yang menjadi sampel penelitian. Variabel terikat yakni hasil belajar mahasiswa dikumpulkan dengan studi dokumentasi yakni nilai akhir mahasiswa yang menjadi sampel penelitian pada mata kuliah yang menerapkan pembelajaran e-learning dengan SIMARI.

Teknik analisis data menggunakan analisis regresi sederhana. Untuk mendukung pembahasan hasil penelitian, tingkat pemanfaatan SIMARI dan hasil belajar dicari reratanya dan kemudian dibuat pengkategorian.

\section{HASIL PENELITIAN DAN PEMBAHASAN}

Berdasarkan hasil analisis data yang dikumpulkan dari sampel penelitian, diperoleh rangkuman terkait variabel bebas yakni pemanfataan SIMARI dan variabel terikat yakni hasil belajar mahasiswa, yang diringkaskan pada Tabel 1 berikut:

Tabel 1

Ringkasan Rerata Skor Variabel Penelitian

\begin{tabular}{llll}
\hline No & Variabel & Rerata Skor & Keterangan \\
\hline 1 & Pemanfaatan SIMARI & 130,63 & Baik \\
& a. Penggunaan e-learning & 93,34 & Baik \\
& b. Hambatan Penggunaan & 37,29 & Rendah \\
2 & Hasil Belajar & 3,63 & Amat Baik \\
\hline
\end{tabular}

Sumber: diolah dari hasil penelitian, 2019 
Dari Tabel 1 terlihat bahwa secara umum Pemanfaatan SIMARI oleh mahasiswa Program Studi Pendidikan Ekonomi sudah baik. Hal ini dapat dimaknai bahwa mahasiswa sudah mampu memanfaatkan SIMARI dengan baik untuk kepentingan kegiatan pembelajarannya. Dilihat dari indikator penggunaan elearning dapat pula dimaknai bahwa mahasiswa sudah mampu menggunakan elearning dengan baik. Dari 10 sub indikator yang ada, skor yang sudah di atas ratarata yakni pada sub indikator: a) penghematan waktu, b) penghematan biaya, c) monitoring aktivitas mahasiswa, dan d) respon terhadap pembelajaran. Enam sub indikator lainnya masih di bawah rata-rata yakni a) kesiapan dalam menggunakan e-learning, b) Memanfaatkan materi, c) pemanfaatan kuis, d) pemanfaatan tugas, e) pemanfaatan forum diskusi, dan f) pemanfaatan chat. Skor tertinggi berada pada sub indikator penghematan waktu sementara skor terendah berada pada sub indikator pemanfaatan forum diskusi.

Dilihat dari indikator hambatan penggunaan, secara umum dapat diinterpretasikan bahwa secara umum mahasiswa tidak mengalami hambatan yang berat dalam penggunaan e-learning untuk kepentingan pembelajaran. Dari empat sub indikator pembentuknya, secara berturut-turut hambatan terbesar yang dialami oleh mahasiswa yakni dari masalah koneksi internet, waktu, keterbatasan interaksi, hingga hambatan terkecil yakni keterbatasan pemahaman. Permasalahan koneksi internet terjadi dikarenakan belum maksimalnya fasilitas wifi yang tersedia di kampus. Terlebih pada saat internet digunakan secara bersama-sama oleh banyak mahasiswa, seringkali terjadi kasus lag yakni tidak berfungsinya internet secara normal akibat over capacity penggunaan oleh mahasiswa.

Hasil belajar mahasiswa yang telah mengikuti pembelajaran berbasis elearning melalui pemanfaatan SIMARI secara umum sudah baik yakni di rata-rata 3,6 atau kategori "Amat Baik". Dari telaah lebih lanjut berdasarkan dokumentasi hasil belajar siswa, 45,2\% mahasiswa memperoleh hasil belajar maksimal (nilai A) dalam pembelajaran berbasis e-learning melalui SIMARI. Hanya 2,7\% mahasiswa yang memperoleh nilai di bawah "B" dan selebihnya berada pada kisaran nilai $\mathrm{B}$ sampai dengan A-. Terindikasi bahwa pemanfaatan SIMARI dalam pembelajaran menjadi salah satu pendukung terhadap peningkatan hasil belajar mahasiswa.

Untuk melihat signifikansi pengaruh pemanfaatan SIMARI dalam pembelajaran berbasis e-learning terhadap hasil belajar mahasiswa dilakukan uji regresi sederhana dengan program SPSS. Hasil uji statistik menunjukkan nilai

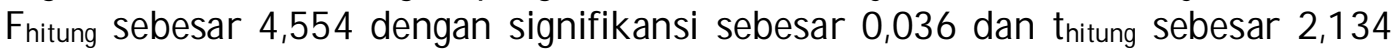
dengan tingkat signifikansi sebesar 0,036. Dapat disimpulkan bahwa pemanfaatan SIMARI sebagai implementasi pembelajaran berbasis e-learning secara signifikan dapat meningkatkan hasil belajar mahasiswa khususnya pada Program Studi Pendidikan Ekonomi FKIP ULM.

Beberapa temuan menarik dari penelitian ini antara lain pemanfaatan SIMARI dalam kegiatan perkuliahan dapat menghemat waktu dikarenakan mahasiswa bisa dimanapun dan kapanpun mengakses segala hal yang terkait dengan proses pembelajaran terutama pada mata-mata kuliah yang telah menerapkan e-learning pada Program Studi Pendidikan Ekonomi FKIP ULM. Mahasiswa tidak perlu berkumpul di suatu tempat (terutama di kelas) serta dapat mengerjakan tugastugas atau ujian melalui SIMARI. Hal ini berdampak positif terhadap pengurangan 
biaya terutama biaya cetak tugas-tugas yang biasanya dikumpulkan dalam bentuk fisik oleh mahasiswa. Penggunaan SIMARI secara tidak langsung telah mendukung pembelajaran paperless dan lebih ramah lingkungan. Dari aspek monitoring dan respon pembelajaran, penggunaan SIMARI membuat mahasiswa lebih perhatian terhadap kegiatan perkuliahan. Mahasiswa akan memantau secara rutin berbagai aktivitas dan tugas-tugas yang harus mereka kerjakan secara online. Aktivitas seperti ini secara otomatis membuat mahasiswa menjadi lebih aktif dalam berbagai aktivitas yang terkait dengan pembelajaran berbasis e-learning.

Temuan penelitian ini senada dengan penelitian-penelitian terdahulu antara lain oleh Darliah (2016), Ratnasari (2012), Mulyadi (2015), serta Huurun'ien, dkk (2017) yang menyimpulkan pengaruh positif dan signifikan dari pemanfaatan elearning terhadap peningkatan hasil belajar. Terlepas dari beragamnya aplikasi, sistem, metode yang digunakan, serta hambatan-hambatan dalam pelaksanaannya, pemanfaatan e-learning secara umum dapat membantu dalam peningkatan kualitas proses hingga hasil belajar peserta didik itu sendiri. Karenanya peningkatan frekuensi dan aktivitas pembelajaran berbasis digital ini perlu lebih dikembangkan khususnya di lingkungan Universitas Lambung Mangkurat sebagai komitmen dalam membangun generasi yang cerdas sekaligus melek teknologi di era Revolusi Industri 4.0.

\section{KESIMPULAN}

Berdasarkan temuan hasil penelitian dapat disimpulkan bahwa pemanfaatan SIMARI sebagai implementasi pembelajaran berbasis e-learning secara signifikan dapat meningkatkan hasil belajar mahasiswa khususnya pada Program Studi Pendidikan Ekonomi FKIP ULM. Dari temuan penelitian ini, peneliti menyarankan beberapa hal untuk peningkatan kualitas dan kuantitas pemanfaatan SIMARI dalam pembelajaran. Dari sisi teknis, pihak universitas dan fakultas khususnya di lingkungan Universitas Lambung Mangkurat perlu sesegera mungkin meningkatkan kapasitas internet sesuai dengan tingkat kebutuhan penggunaannya. Kelancaran internet merupakan faktor utama dari sisi teknis yang menurut sudut pandang tim peneliti yang paling berpengaruh terhadap keberhasilan pembelajaran berbasis e-learning. Rekomendasi lain yang diajukan yakni perlunya sosialisasi dan workshop yangg lebih intens kepada para dosen serta sistem rewards dalam rangka meningkatkan minat dan kepedulian dosen untuk menerapkan pembelajaran berbasis e-learning. Dosen sebagai salah satu faktor kunci dalam sebuah proses pembelajaran di universitas perlu memiliki pemahaman yang holistik tentang kebermanfaatan e-learning dalam proses perkuliahan di era digital saat ini. Meningkatkan pemahaman dosen akan menjadi kunci untuk merubah sudut pandang dalam rangka pengembangan pembelajaran bagi mahasiswa yang lebih bermakna dan sesuai dengan tuntutan jaman. 


\section{DAFTAR PUSTAKA}

Darliah, Lili. 2016. Pengaruh Kualitas Informasi dan Penggunaan E-learning terhadap Prestasi Belajar sebagai Variabel Intervening (Studi Kasus pada Mahasiswa Pendidikan Ekonomi FE UNY 2012-2013). Yogyakarta: FE Universitas Negeri Yogyakarta.

Darmawan, Deni. 2014. Pengembangan E-learning Teori dan Desain. Bandung: PT Remaja Rosdakarya.

Elyas, Ananda Hadi. 2018. Penggunaan Model Pembelajaran E-learning Dalam Meningkatkan Kualitas Pembelajaran. Jurnal Warta Edisi: 56 April 2018.

Huurun'ien, Kansha Isfaraini. Efendi, Agus. Tamrin, A. G. 2017. Efektivitas Penggunaan E-learning Berbasis Schoology dengan Menggunakan Model Discovery Learning terhadap Prestasi Belajar Siswa pada Mata Pelajaran Sistem Komputer Kelas X Multimedia SMK Negeri 6 Surakarta pada Tahun Pelajaran 2015/2016. Jurnal Ilmiah Pendidikan Teknik dan Kejuruan 10 (2), Juli 2017.

Kristiawan, M. 2014. A Model for Upgrading Teachers Competence on Operating Computer as Assistant of Instruction. Global Journal of Human-Social Science Research 14 (5).

Mulyadi, Rindy.2015. Pengaruh Pemanfaatan E-learning Menggunakan "Portal Rumah Belajar Kemendikbud" terhadap Hasil Belajar Siswa pada Mata Pelajaran Ilmu Pengetahuan Alam: Kuasi Eksperimen di SMPN 1 Lembang Materi Pokok Sistem Gerak Pada Manusia. Bandung: Universitas Pendidikan Indonesia.

Ramadhani, Mawar. 2012. Efektivitas Penggunaan Media Pembelajaran E-learning Berbasis Web pada Pembelajaran Teknologi Informasi dan Komunikasi terhadap Hasil Belajar Siswa Kelas X SMAN 1 Kalasan. Yogyakarta: Fakultas Teknik UNY.

Ratnasari, Intan. 2012. Peran Teknologi Internet terhadap Peningkatan Motivasi Belajar dan Prestasi Belajar Mahasiswa Program Pendidikan Teknik Mesin JPTK FKIP UNS Angkatan 2009. Surakarta: Universitas Negeri Surakarta.

Rusman, dkk. (2011). Pembelajaran Berbasis Teknologi Informasi dan Komunikasi mengembangkan Profesionalitas Guru. Jakarta: PT Rajagrafindo Persada.

Soekarwati. (2003). Pengembangan E-learning Teori dan Desain. Bandung: PT Remaja Rosdakarya.

Yustanti, Ika. Novita, Dian. (2019). Pemanfaatan E-learning bagi Para Pendidik di Era Digital 4.0. Prosiding Seminar Nasional Pendidikan Program Pascasarjana Universitas PGRI Palembang 12 januari 2019. 